\title{
Pemodelan Spasial Erosi Kualitatif Berbasis Raster (Studi Kasus di DAS Serang, Kabupaten Kulonprogo)
}

\author{
Nursida Arif 1,2 , Projo Danoedoro², dan Hartono² \\ 1Fakultas Sains dan Teknologi, Universitas Muhammadiyah Gorontalo; e-mail: nursida.arif@gmail.com \\ 2Fakultas Geografi, Universitas Gadjah Mada
}

\begin{abstract}
ABSTRAK
Erosi merupakan salah satu fenomena alam yang banyak dikaji karena melibatkan banyak faktor yaitu vegetasi, tanah, iklim, topografi dan manusia. Kompleksitas faktor-faktor yang mempengaruhi erosi disederhanakan melalui pemodelan untuk memprediksi tingkat erosi pada suatu wilayah dengan memanfaatkan data penginderaan jauh dan sistem informasi geografis. Faktor yang digunakan dalam menyusun model hanya melibatkan tiga faktor yaitu vegetasi, tanah dan lereng. Penelitian ini dilakukan di DAS Serang karena termasuk salah satu DAS yang berada dalam kondisi kritis yang dapat memicu terjadinya degradasi lahan, erosi dan longsor. Tujuan penelitian ini adalah mengetahui distribusi spasial tingkat erosi kualitatif di DAS Serang. Pendekatan yang digunakan adalah integrasi peginderaan jauh dan sistem informasi geografis berbasis raster. Validasi model dilakukan dengan melihat faktor topografi dan indikator erosi kualitatif di lapangan yaitu armour layer, singkapan akar, pedestal, erosi alur dan gully. Hasil penelitian menunjukan model yang dihasilkan sangat efektif sebagai solusi cepat prediksi erosi. Berdasarkan hasil analisis tingkat erosi sangat berat mendominasi di wilayah kajian yaitu sebagian besar di kecamatan Kokap, Girimulyo dan sebagian Pengasih.
\end{abstract}

Kata kunci: Erosi, Model, Kualitatif, DAS Serang

English Title: Spatial Modeling of Raster Based Qualitative Erosion

\begin{abstract}
Erosion is one of the natural phenomena that's studied by many because it involves many factors, namely vegetation, soil, climate, topography and humans. The complexity of the factors affecting erosion is simplified through modeling to predict of erosion rates in a region by utilizing remote sensing data and geographic information systems. The erosion control factor used in this research fewer parameters, namely vegetation, soil and topography only. This research was conducted in Serang watershed because it is one of the watersheds which are in critical conditions which can trigger land degradation, erosion and landslides. The purpose of this research was to know the spatial distribution of erosion susceptibility levels in Serang watershed. The approach used was the integration of remote sensing and raster-based geographic information system. Model validation was undertaken based on topograhy factor and observation of qualitative erosion indicators in the field. The indicators used were pedestals, armor layers, root exposure, or other erosion featuress such as rill and gullies. The results show that the resulting model is more effective as a quick solution to the prediction of erosion. Based on the results of the analysis, the spatial distribution of erosion rates is very dominant in the study area, mostly in Kokap, Girimulyo and some of the subdistricts.
\end{abstract}

Keywords: Erosion, Modeling, Qualitative, Serang watershed

Citation: Arif, N., Danoedoro, P., dan Hartono. (2017). Pemodelan Spasial Erosi Kualitatif Berbasis Raster (Studi Kasus di DAS Serang, Kabupaten Kulonprogo). Jurnal Ilmu Lingkungan, 15(2),127-134, doi:10.14710/jil.15.2.127-134

\section{Pendahuluan}

Erosi merupakan proses terlepasnya butiran atau bagian-bagian tanah dari suatu tempat ketempat lain karena terangkut oleh air atau angin (Arsyad, 2010). Erosi menjadi alat ukur penting bagi para pengguna lahan maupun pengambil keputusan untuk mengevaluasi tata kelola lahan. Oleh karena itu pemetaan tingkat erosi melalui pemodelan sangat penting dilakukan untuk merepresentasikan kenyataan di lapangan. Pemodelan erosi dapat dilakukan dengan memanfaatkan data penginderaan jauh dan sistem informasi geografis. Data penginderaan jauh diandalkan dalam memperoleh informasi landscape seperti vegetasi dan penggunaan lahan. Sedangkan SIG digunakan untuk mengolah, mensimulasikan skenario dan memvisualisasikan hasil pemodelan. Beberapa penelitian dilakukan khususnya dibidang terapan lingkungan termasuk 
untuk kajian erosi dan longsor membuktikan bahwa integrasi SIG dan PJ lebih akurat dan efektif (Asis dan Omasa, 2007; Pradhnan dan Lee., 2007; Pradhan, Lee, dan Buchroitner., 2010; Liao et al., 2012).

Farhan, Zregat dan Farhan (2013) menggunakan persamaan model RUSLE dalam kalkulasi setiap nilai parameter, hasilnya menunjukan integrasi penginderaan jauh dan SIG dapat menghasilkan model yang lebih sederhana dalam estimasi erosi, walaupun model yang dihasilkan dapat mengetahui faktor yang mempengaruhi erosi dan estimasi besaran tanah yang hilang di wilayah kajian namun hasil model tidak dikalibrasi dengan data aktual erosi di lapangan. Karena untuk menghasilkan model kuantitatif yang dapat merepresentasikan kondisi nyata dilapangan secara akurat membutuhkan pengukuran yang detil dengan waktu yang lama sehingga biaya lebih mahal. Metode kuantitatif dalam estimasi erosi membutuhkan pemantauan yang intensif dan lebih rinci mengenai kondisi suatu lahan (Ypsilantis, 2011).

Penelitian ini menggunakan pendekatan berbeda dengan menyederhanakan faktor yang berbeda untuk menilai tingkat erosi yaitu hanya berdasarkan faktor vegetasi menggunakan indeks faktor manajemen dan tutupan vegetasi (C), faktor tanah menggunakan indeks erodibilitas $(\mathrm{K})$ dan topografi menggunakan indeks panjang dan kemiringan lereng (LS). Vrieling, Sterk dan Vigiak (2006) dalam penelitiannya hanya menggunakan faktor vegetasi dan lereng dalam prediksi erosi dan menghasilkan akurasi $80 \%$. Padahal dalam beberapa penelitian selain kedua faktor tersebut, faktor erodibilitas tanah juga memberikan pengaruh terhadap terjadinya erosi (Farhan, Zregat dan Farhan, 2013; Kamaludin et al., 2013)
Pendekatan yang digunakan dalam penelitian ini adalah pendekatan kualitatif dimana keluaran model (output) tidak menampilkan informasi besaran prediksi erosi secara kuantitatif tetapi tingkatan secara kualitatif karena besaran nilai secara numerik suatu variabel pada dasarnya adalah nilai yang bisa berubah pada periode tertentu sedangkan pada kualitatif cenderung lebih konstan dan tidak berubah (Bredeweg et al., 2009). Model erosi kuantitatif dapat diandalkan untuk melihat perubahan dinamis dari karakteristik produktivitas lahan, namun memiliki dasar empiris yang lemah, sulit diterapkan pada skala nasional dan membutuhkan interpretasi yang cermat (Sonneveld, Keyzar, dan Stroosnijder, 2011).

Tujuan dari penelitian ini adalah mengetahui distribusi spasial prediksi tingkat erosi secara kualitatif menngunakan citra penginderaan jauh dan SIG. Model erosi kualitatif yang dibangun tidak ditentukan berdasarkan hasil tumpangsusun skor data-data input parameter tetapi berdasarkan data latih (training data) menggunakan klasifikasi jaringan saraf tiruan. Dibutuhkan justifikasi awal kelas tingkat erosi secara kualitatif. Definisi masingmasing kelas tingkat erosi secara kualitatif merupakan hasil perhitungan erosi dan tingkat bahaya erosi yang divalidasi dengan pengamatan indikator erosi di lapangan seperti pedestal, armour layer, singkapan akar dan tree mound yang telah digunakan oleh Stocking dan Murnaghan (2000). Dengan pendekatan kualitatif yang dilakukan dapat menjadi metode alternatif dalam pemetaan erosi yang lebih cepat dan akurat.

Penelitian ini dilakukan di DAS Serang karena termasuk salah satu DAS yang berada dalam kondisi kritis yang dapat memicu terjadinya degradasi lahan, erosi dan longsor seperti yang ditunjukan oleh Gambar 1.

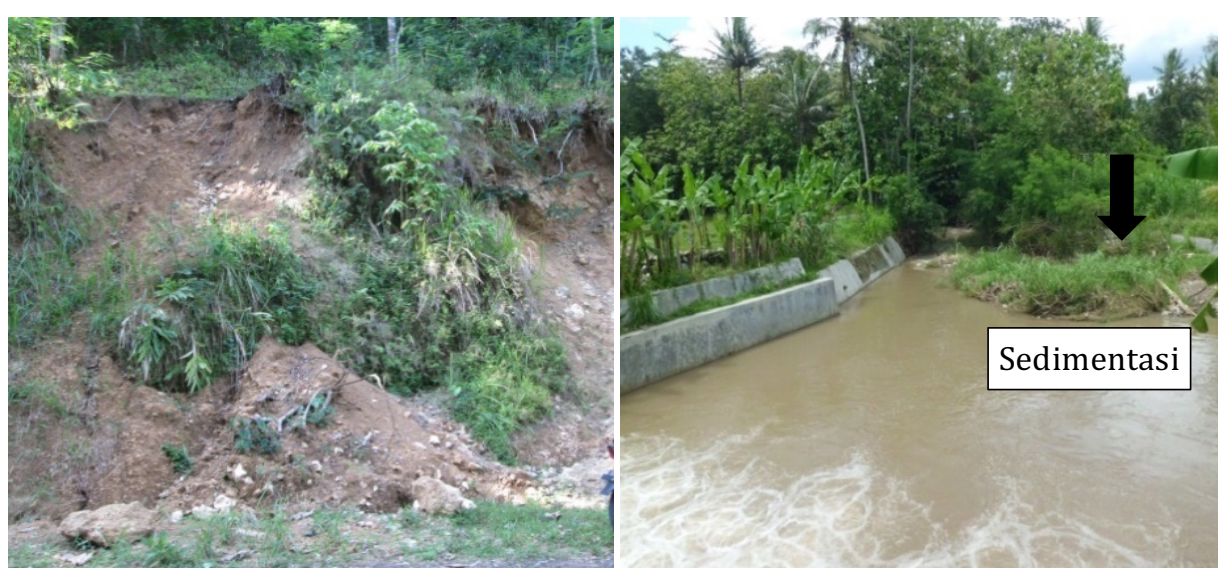

Gambar 1 Indikator Terjadinya Erosi

(a) Kenampakan longsor lahan (401181 mT, $9132420 \mathrm{mU}$, Foto Februari 2015)

(b) Kenampakan sedimentasi (4 08105 mT, 9136568 mU, Foto Desember 2014)

\section{Metode Penelitian}

\subsection{Bahan dan Alat yang di Gunakan}

Perangkat lunak (software) yang digunakan terdiri dari beberapa software untuk kepentingan analisis yang berbeda yaitu (1) ENVI 4.8 untuk pengolahan citra pra-pemrosesan (koreksi geometrik, radimetrik, tranformasi citra); (2) ArcGIS 10.2 untuk pengolahan data-data non spektral 
Arif, N., Danoedoro, P., dan Hartono. (2017). Pemodelan Spasial Erosi Kualitatif Berbasis Raster (Studi Kasus di DAS Serang, Kabupaten Kulonprogo). Jurnal Ilmu Lingkungan, 15(2),127-134, doi:10.14710/jil.15.2.127-134

(interpolasi) dan visualisasi peta hasil pemodelan; (3) IDRISI Selva untuk pengolahan dan analisis model erosi kualitatif.

Peralatan lapangan yang digunakan meliputi Global Positioning System (GPS) Garmin seri 76 CsX untuk navigasi dan plotting titik sampel dilapangan atau posisi kenampakan hasil erosi, Abney level untuk mengukur kemiringan lereng, Alat tulis untuk mencatat data hasil survei lapangan, Kamera untuk memotret kondisi lapangan, Ring untuk sampel tanah

Bahan yang digunakan dalam menunjang data penelitian yaitu Citra SPOT 5 tanggal perekaman 24 Oktober 2014 untuk menurunkan informasi faktor C, Peta RBI skala 1:25.000 lembar Kulonprogo, Peta tanah skala 1: 50.000 untuk penentuan titik sampel tanah

\subsection{Penyusunan Parameter Erosi}

Parameter erosi yang digunakan dalam penelitian diturunkan dari tiga faktor erosi yaitu vegetasi menggunakan parameter indeks manajemen dan tutupan vegetasi $(\mathrm{C})$, erodibilitas $(\mathrm{K})$, panjang dan kemiringan lereng (LS).

Nilai faktor C diperoleh dari transformasi indeks vegetasi yang dilakukan pada citra SPOT 5 hasil koreksi yaitu dengan terlebih dahulu menghitung nilai NDVI menggunakan Persamaan 1.

$$
\mathrm{NDVI}=\frac{\text { band } 3-\text { band } 2}{\text { band } 3+\text { band } 2} \text {. }
$$

Nilai C dihitung menggunakan persamaan yang sama dengan yang digunakan oleh Gutman dan Ignatov (1998):

$$
\mathrm{C}=1-\frac{N D V I-N D V I_{\min }}{N D V I_{\max }-N D V I_{\min }}
$$

Nilai faktor LS diperoleh dari data kontur dengan menghitung panjang dan kemiringan lereng menggunakan Persamaan 3 dan Persamaan 6 yang dikembangkan oleh McCool, Brown dan Foster (1989):

Dimana :

$$
\begin{aligned}
& \mathrm{L}=\left(\frac{\lambda}{22.13}\right)^{\beta} \\
& \beta=\frac{\left(\frac{\sin \theta}{0.0896}\right) /\left[3 *(\sin \theta)^{0.8}+0.56\right]}{1+\left(\frac{\sin \theta}{0.0896}\right) /\left[3 *(\sin \theta)^{0.8}+0.56\right]} \text {. } \\
& \lambda=\text { Flow accumulation } x \text { cellsize } \\
& \left\{10.8 \sin \theta+0.03 \theta \quad \theta<5^{\circ}\right. \\
& S=\left\{\begin{array}{c}
16.8 \sin \theta-0.55^{\circ} \leq \theta<10^{\circ} \\
21.9 \sin \theta-0.96 \quad \theta \geq 10^{\circ}
\end{array}\right.
\end{aligned}
$$

$\mathrm{L}=$ Panjang lereng

$\mathrm{S}=$ Kecuraman Lereng

$\Theta=$ Nilai slope dari DEM

$\lambda=$ Panjang horisontal slope

$\beta=$ Indeks slope

Nilai erodibilitas diperoleh dari data sampel tanah hasil uji laboratorium. Jenis data tanah yang diambil sampelnya adalah tekstur tanah, bahan organik dan permeabilitas tanah. Faktor K dihitung menggunakan persamaan RUSLE (Persamaan 7) yang dikembangkan oleh Renard et al. (1997):

$K=7.594\left\{0.0017+0.049 \exp \left[-\frac{1}{2}\left(\frac{\log (D g)+1.675}{0.6986}\right)^{2}\right]\right\} \ldots . .(7)$

dimana :

$\mathrm{K}=$ Erodibilitas tanah

Dg = Diameter partikel geometrik tanah $(\mathrm{mm})$.

Distribusi nilai K pada area penelitian diprediksi menggunakan beberapa metode interpolasi pada nilai $\mathrm{K}$ hasil data sampel. Masing-masing hasil metode interpolasi diuji akurasi menggunakan RMSE (root mean square error) pada Persamaan 8

$$
\mathrm{RMSE}=\sqrt{\frac{\sum_{i}^{n}\left(A_{i}-P_{i}\right)^{2}}{n}}
$$

dimana :

$\mathrm{n}=$ Jumlah sampel

$A_{i}=$ Nilai hasil pengukuran lapangan di titik i

$\mathrm{P}_{\mathrm{i}}=$ Nilai hasil prediksi di titik $\mathrm{i}$

\section{Hasil dan Pembahasan}

\subsection{Faktor Erodibilitas Tanah}

Sampel yang digunakan untuk prediksi erodibilitas yaitu 52 sampel tanah yang dibagi menjadi dua sampel yaitu 37 sampel untuk prediksi nilai erodibilitas pada keseluruhan lokasi penelitian dengan menggunakan berbagai metode interpolasi dan 15 sampel digunakan untuk uji ketelitian hasil interpolasi dengan menghitung RMSE. Metode interpolasi nilai $\mathrm{K}$ dilakukan menggunakan beberapa metode yang tersedia pada software ArcGIS yaitu IDW, spline, kriging. Hasil uji RMSE menunjukan hasil interpolasi menggunakan IDW memiliki akurasi lebih baik seperti yang ditunjukan pada Tabel 1. Peta erodibilitas hasil interpolasi IDW disajikan pada Gambar 2.

Tabel 1. Perbandingan RMSE Hasil Interpolasi.

\begin{tabular}{cc}
\hline Metode Interpolasi & RMSE \\
\hline IDW & 0,058 \\
Spline & 0,101 \\
Kriging & 0,06 \\
\hline
\end{tabular}

Sumber :Analisis, 2016

Jika dilihat distribusi secara spasial (Gambar 2) maka area penelitian termasuk rentan terhadap erosi dimana erodibilitas tinggi tersebar hampir diseluruh area penelitian yaitu di kecamatan Panjatan, Wates, Kokap, Pengasih, Girimulyo dan sebagian Nanggulan.

\subsection{Faktor Panjang dan Kemiringan Lereng (LS)}

Hasil analisis pada faktor LS di lokasi penelitian diperoleh rentang nilai terendah 0,03 dan tertinggi 427,50 (Lihat Gambar 3). Nilai LS yang kecil maka potensi erosi juga kecil, demikian sebaliknya Nilai LS besar maka potensi erosi juga besar. Horton (1945) menunjukan bahwa erosi lebih meningkat pada 
lereng yang panjang dan curam karena peningkatan kekuatan geser pada permukaan tanah.

Gambar 3 menunjukan distribusi spasial indeks LS terendah mendominasi di Kecamatan Wates, Temon, Panjatan dan sebagian Pengasih dan Nanggulan. Sedangkan distribusi indeks LS tinggi tersebar di kecamatan Kokap dan Girimulyo, artinya pada wilayah ini potensi terjadinya erosi lebih tinggi.

\subsection{Faktor Manajemen dan Tutupan Vegetasi (C)}

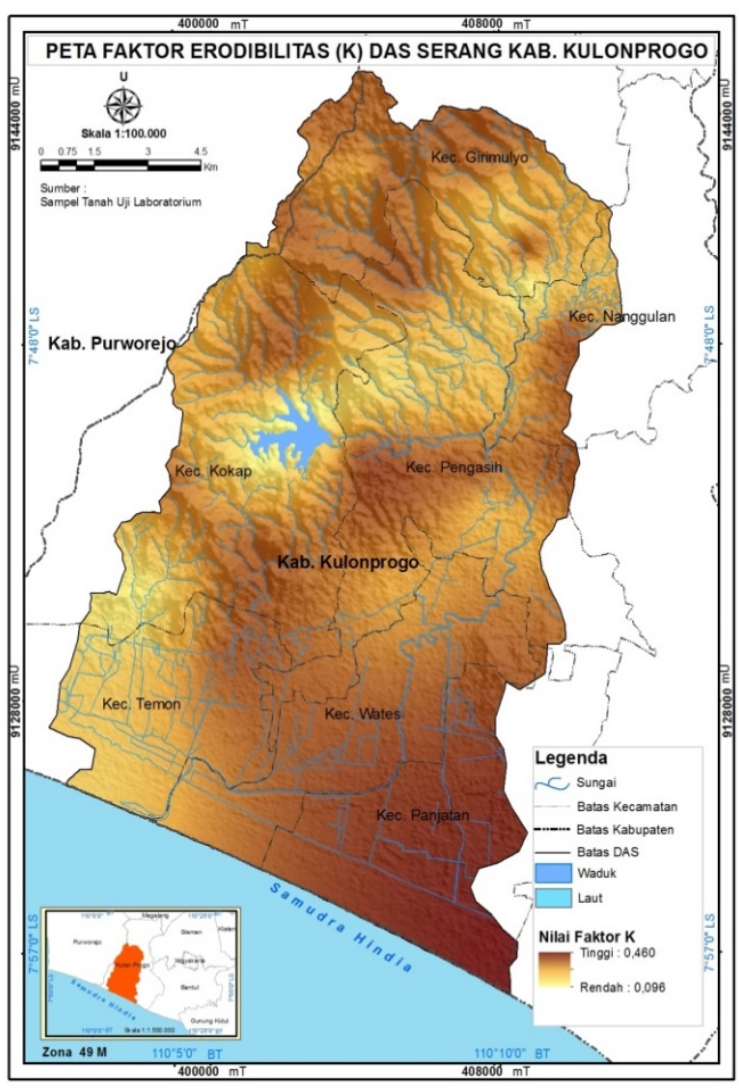

Gambar 2. Peta Faktor K DAS Serang
Pada penelitian ini, nilai $\mathrm{C}$ diperoleh dari hasil transformasi NDVI menggunakan Persamaan 2 . Beberapa penelitian membuktikan metode NDVI memiliki korelasi dengan faktor $\mathrm{C}$ dan lebih optimal digunakan pada area yang lebih luas dalam waktu yang singkat (Farhan, Zregat dan Farhan, 2013; Alexakis, Hadjimitsis dan Agapiou, 2013). Hubungan NDVI dengan faktor $\mathrm{C}$ berbanding terbalik, semakin baik tutupan vegetasi (NDVI makin tinggi) maka nilai $\mathrm{C}$ makin rendah seperti yang tampak pada Gambar 4.

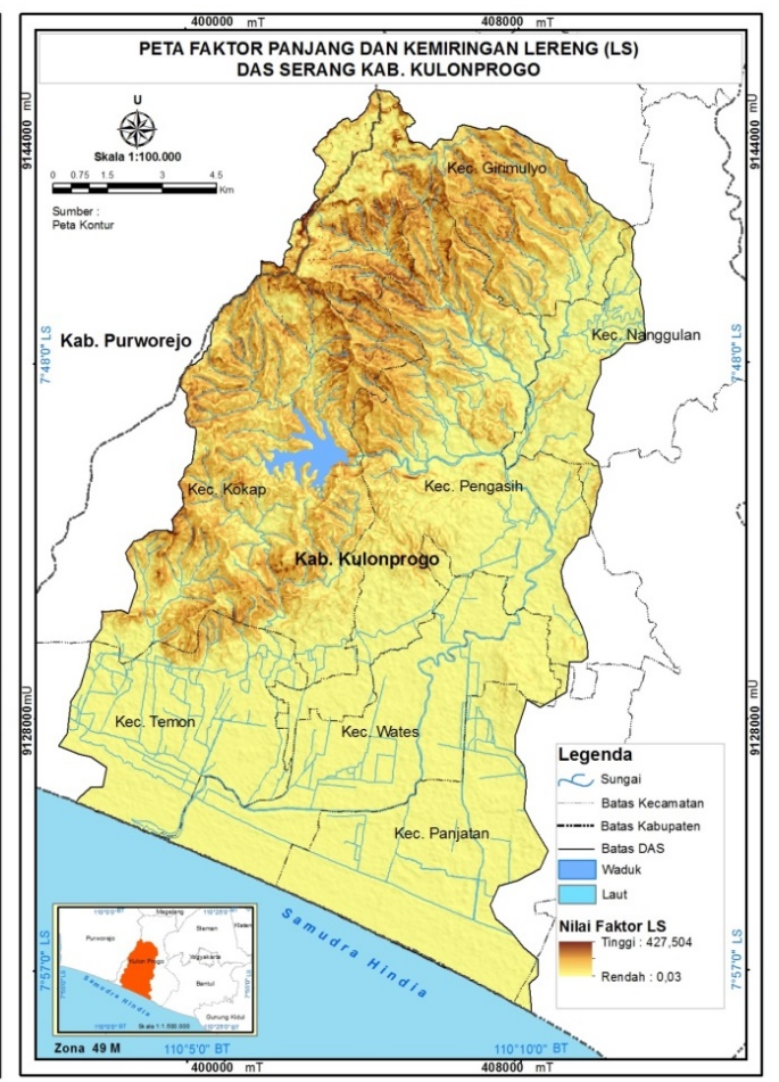

Gambar 3. Peta Faktor K DAS Serang

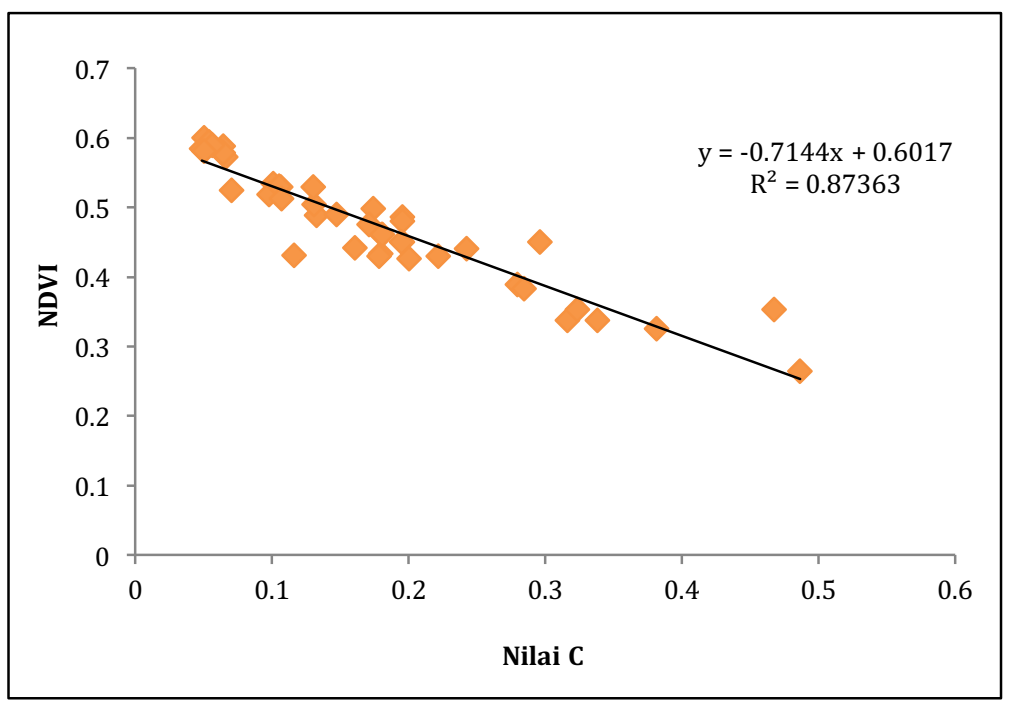

Gambar 4. Peta Faktor K DAS Serang 
Arif, N., Danoedoro, P., dan Hartono. (2017). Pemodelan Spasial Erosi Kualitatif Berbasis Raster (Studi Kasus di DAS Serang, Kabupaten Kulonprogo). Jurnal Ilmu Lingkungan, 15(2),127-134, doi:10.14710/jil.15.2.127-13

Peta faktor $\mathrm{C}$ menunjukan nilai indeks $\mathrm{C}$ pada DAS Serang terendah 0,01 dan tertinggi 1,426 seperti yang disajikan pada peta nilai C (Gambar 4). Indeks nilai $\mathrm{C}$ tinggi terdapat di kecamatan wates, Temon dan Panjatan dimana penggunaan lahan yang ditemukan yaitu sawah sedangkan indeks $\mathrm{C}$ rendah terdapat di kecamatan Kokap, Pengasih, Girimulyo dan sebagian Nanggulan.

Nilai C yang diperoleh peneliti dari hasil turunan NDVI beberapa berbeda dengan nilai $C$ hasil penelitian terdahulu. Beberapa hal yang mendasari perbedaan indeks $\mathrm{C}$ nilai yaitu bulan pengamatan, perbedaan iklim termasuk curah hujan serta lokasi pengamatan yang berbeda kondisi dengan lokasi penelitian. Berdasarkan hal tersebut, nilai indeks C bukan merupakan nilai absolut yang tidak mengalami perubahan setiap periodik (musim/tahun), sehingga sangat memungkinkan adanya perbedaan pada setiap peneliti.

Ketiga peta faktor pengontrol erosi diatas yaitu Gambar 2, Gambar 3 dan Gambar 5 akan dianalisis berbasis raster menggunakan teknik jaringan saraf tiruan (JST). Teknik JST digunakan karena JST mampu memahami data non linear dan kompleks (Melchiorre et al., 2008; Arif dan Danoedoro, 2013).
Penelitian ini tidak mengkaji secara mendalam pengaruh parameter JST dalam menghasilkan akurasi hasil prediksi, sehingga parameter yang digunakan hanya berdasarkan kombinasi dengan akurasi terbaik yang dilakukan oleh peneliti terdahulu (Arif dan Danoedoro, 2013; Chen et al., 2013; Song et al 2013). Proses simulasi prediksi erosi dilakukan pada software IDRISI Selva.

Metode JST membutuhkan data contoh (sampel) sebagai data latih. Jumlah sampel yang digunakan adalah 53 sampel, jumlah sampel yang dilatih yaitu 30 sampel mewakili karakteristik data berbeda. Definisi kelas erosi hasil justifikasi berdasarkan analisis yang dilakukan disajikan pada Tabel 2. Peta hasil prediksi disajikan pada Gambar 6.

Berdasarkan Gambar 6 menunjukan tingkat erosi yang dominan adalah erosi sangat berat terdapat khususnya di lereng yang curam. Pada lereng yang datar terdapat tingkat erosi berat yaitu di kecamatan Panjatan dan sebagian Wates. Hal ini karena erodibilitas pada wilayah tersebut termasuk dalam kelas erosi tinggi (Gambar 2). Artinya faktor erodibiltas dan lereng memberikan pengaruh yang lebih besar dibandingkan faktor vegetasi.

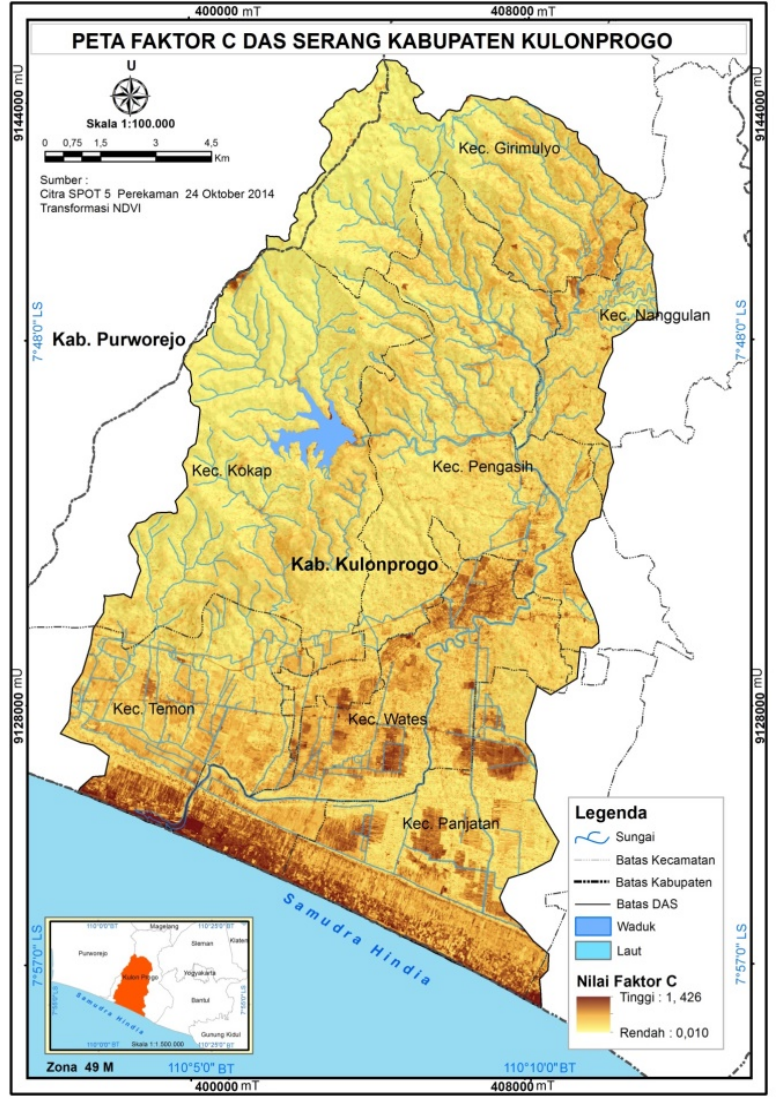

Gambar 5. Peta Faktor C DAS Serang

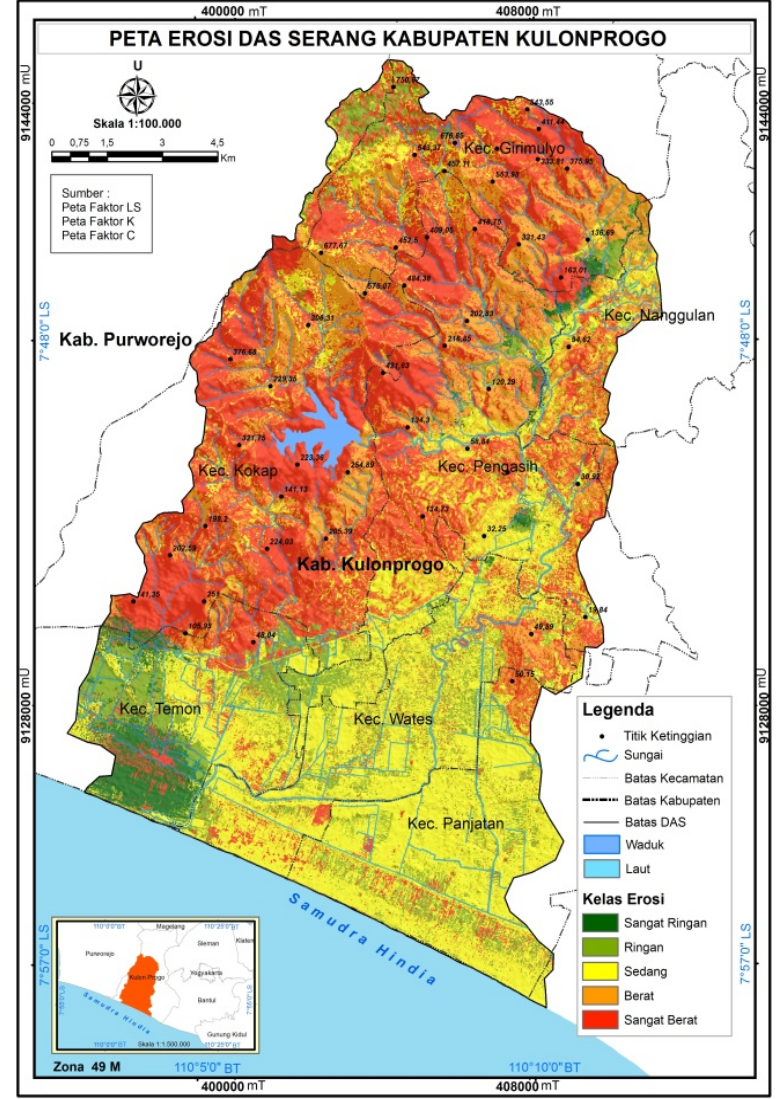

Gambar 6. Peta Hasil Prediksi Erosi DAS Serang 
Tabel 2. Definisi Sampel Erosi di Lokasi Penelitian

\begin{tabular}{|c|c|c|c|c|c|c|c|c|c|c|c|}
\hline \multirow{3}{*}{ Kelas Erosi } & \multicolumn{6}{|c|}{ Indikator Erosi Kualitatif } & \multicolumn{5}{|c|}{ Kemiringan lereng } \\
\hline & \multirow{2}{*}{$\begin{array}{c}\text { Tidak } \\
\text { ada }\end{array}$} & \multicolumn{5}{|c|}{ Ada } & \multirow[b]{2}{*}{ I } & \multirow[b]{2}{*}{ II } & \multirow[b]{2}{*}{ III } & \multirow[b]{2}{*}{ IV } & \multirow[b]{2}{*}{$\mathrm{V}$} \\
\hline & & $\begin{array}{c}\text { Singkapan } \\
\text { akar }\end{array}$ & Pedestal & $\begin{array}{c}\text { Armour } \\
\text { layer }\end{array}$ & $\begin{array}{c}\text { Erosi alur } \\
(\text { rill })\end{array}$ & $\begin{array}{c}\text { Erosi parit } \\
\text { (gully) }\end{array}$ & & & & & \\
\hline \multirow{3}{*}{$\begin{array}{l}\text { Sangat ringan } \\
\text { ringan }\end{array}$} & $\checkmark$ & & & & & & $\checkmark$ & & & & \\
\hline & $\checkmark$ & & & & & & & $\checkmark$ & & & \\
\hline & & $\checkmark$ & $\checkmark$ & $\checkmark$ & & & $\checkmark$ & & & & \\
\hline \multirow[t]{2}{*}{ Sedang } & & $\checkmark$ & $\checkmark$ & $\checkmark$ & & & & $\checkmark$ & & & \\
\hline & $\checkmark$ & & & & & & & & $\checkmark$ & & \\
\hline \multirow[t]{2}{*}{ Berat } & & & & & $\checkmark$ & & & $\checkmark$ & & & \\
\hline & & $\checkmark$ & $\checkmark$ & & & & & & $\checkmark$ & & \\
\hline \multirow[t]{2}{*}{ Sangat berat } & & & & & & $\checkmark$ & & & $\checkmark$ & $\checkmark$ & $\checkmark$ \\
\hline & & $\checkmark$ & $\checkmark$ & & $\checkmark$ & & & & & $\begin{array}{l}\checkmark \\
\checkmark\end{array}$ & $\begin{array}{l}\checkmark \\
\checkmark\end{array}$ \\
\hline
\end{tabular}

Keterangan:I=datar; II=landai; III=agak curam; IV=curam; V=sangat curam

Sumber : Hasil pengamatan lapangan, 2015

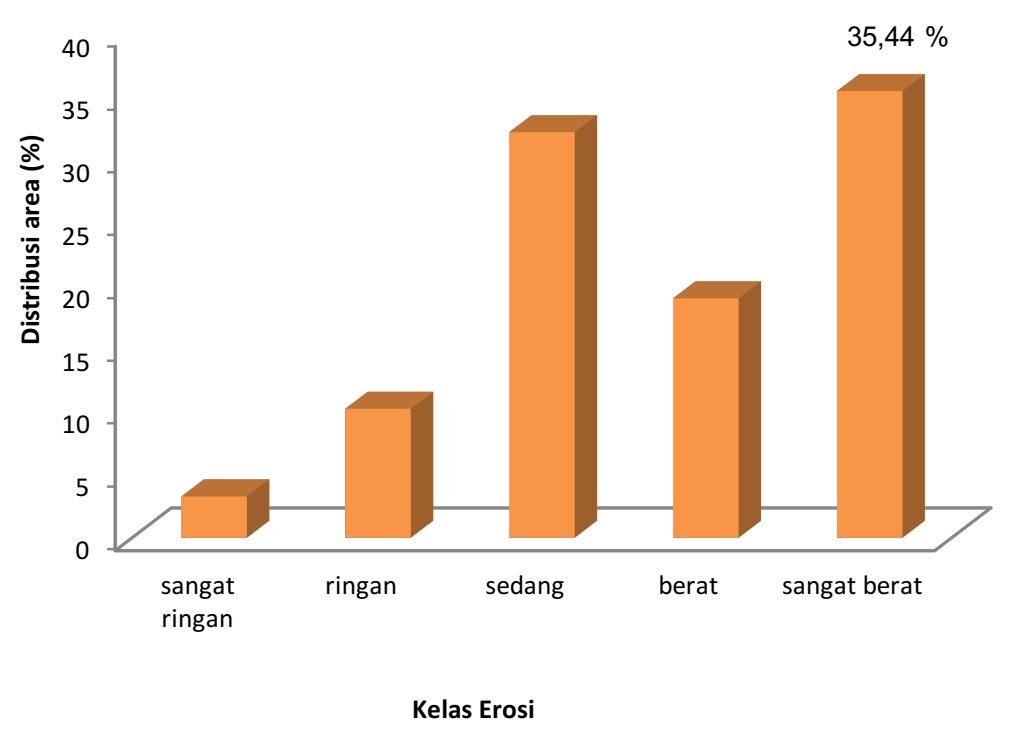

Gambar 7. Persentase Distribusi Tingkat Erosi

Peta pada Gambar 6 persentase distribusi spasial kelas erosi didominasi oleh erosi berat $(35,44 \%)$ kemudian berturut erosi sedang $(32,16 \%)$, erosi ringan $(10,18 \%)$ dan erosi sangat ringan $(3,26 \%)$ seperti yang disajikan pada Gambar 7 . Hal yang sama ditunjukan oleh peneliti terdahulu bahwa DAS Serang termasuk dalam kondisi kritis dan buruk (Santoso, 2012; Purnomojati, 2016).

Validasi model berdasarkan hasil pengamatan indikator erosi kualitatif seperti yang ditunjukan pada beberapa sampel berikut (Gambar 8 dan Gambar 9). Kenampakan erosi pada Gambar 8 adalah pedestal dan singkapan akar yang terjadi pada lereng yang curam merupakan tingkat erosi sangat berat mengacu pada justifikasi kelas erosi Tabel 2. Pedestal dan singkapan akar menjadi indikator laju erosi tinggi karena terjadi pada tanah yang mudah terkikis (erodibilitas tinggi) oleh intensitas curah hujan tinggi (Stocking dan Murnaghan, 2000).

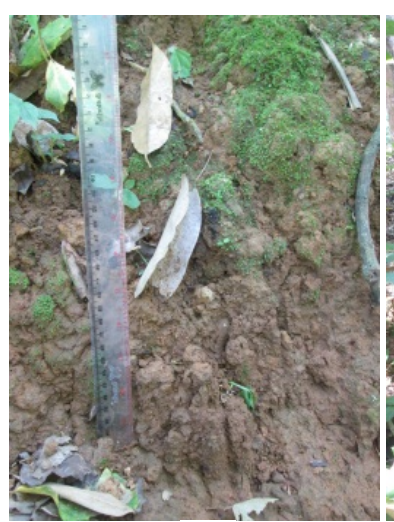

(a)

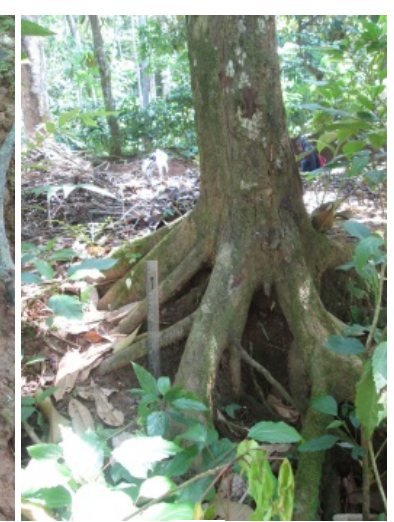

(b)
Gambar 8. Kelas Tingkat Erosi Sangat Berat

(a) Kenampakan Pedestal

(b) Kenampakan singakapn akar Lokasi: $400202 \mathrm{mT}$; $9138238 \mathrm{mU}$ 


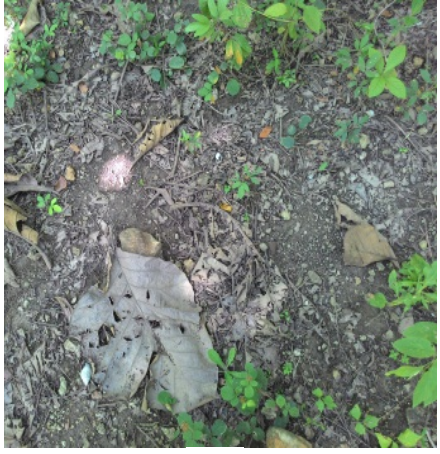

(a)

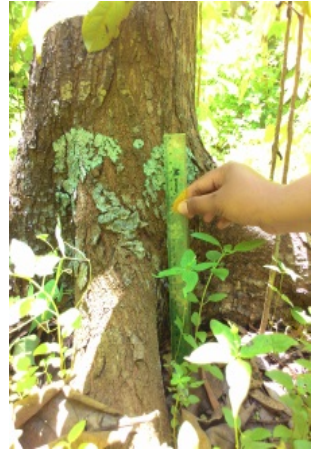

(b)
Gambar 9. Kelas Tingkat Erosi Sedang

(a) Kenampakan armour layer

(b) Kenampakan singakapan akar

Lokasi: 407702 mT; 9129856 mU

Gambar 9 dijustifikasi sebagai erosi sedang karena berada di lereng yang landai. Lereng menjadi indikator yang penting yang mempengaruhi terjadinya erosi. Vrieling, Sterk dan Vigiak O (2006) menegaskan bahwa lereng sangat curam memiliki kelas erosi yang tinggi. Semakin miring lereng, maka partikel yang terhambur ke lereng bawah makin banyak sehingga memicu terjadinya erosi percik dan erosi alur Assouline dan Ben-Hur ( 2006). Validasi pada keseluruhan sampel menghasilkan akurasi 83,02\% (Tabel 3). Berdasarkan evaluasi pada proses yang dilakukan dan keluaran model (output) yang dihasilkan, model sangat fleksibel dengan data input yang terbatas dapat digunakan untuk memprediksi tingkat erosi, model dapat diadaptasi pada DAS sejenis. Kelemahannya tingkat generalisasi rendah berbeda dengan model hasil analisis vektor dimana generalisasi lebih tinggi, namun gangguan bentang lahan yang lain seringkali diabaikan dalam pembuatan poligon. Distribusi spasial berbasis raster sulit diterapkan untuk upaya konservasi lahan sehingga kontrol erosi menjadi lebih sulit.

Tabel 3. Matriks Kesalahan Pengujian Keseluruhan Sampel

\begin{tabular}{|c|c|c|c|c|c|c|c|c|}
\hline \multirow{2}{*}{\multicolumn{2}{|c|}{ Klas Erosi }} & \multicolumn{5}{|c|}{ Ground truth } & \multirow[b]{2}{*}{ Total } & \multirow[b]{2}{*}{ User's accuracy (\%) } \\
\hline & & $\begin{array}{l}\text { Sangat } \\
\text { ringan }\end{array}$ & Ringan & Sedang & Berat & $\begin{array}{c}\text { Sangat } \\
\text { berat }\end{array}$ & & \\
\hline \multirow{5}{*}{ 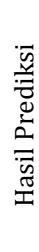 } & Sangat ringan & 3 & & 1 & & & 4 & 75,00 \\
\hline & Ringan & & 5 & 1 & & & 6 & 83,33 \\
\hline & Sedang & 1 & & 5 & & & 6 & 83,33 \\
\hline & Berat & & & & 5 & 2 & 7 & 71,43 \\
\hline & Sangat berat & & & & 4 & 26 & 30 & 86,67 \\
\hline \multirow{3}{*}{\multicolumn{2}{|c|}{$\begin{array}{c}\text { Total sampel } \\
\text { Produser's acc. (\%) } \\
\text { Overall accuracy (\%) }\end{array}$}} & 4 & 5 & 7 & 9 & 28 & 53 & \\
\hline & & 75 & 100 & 71,42 & 55,55 & 92,85 & & \\
\hline & & 83,02 & & & & & & \\
\hline & Kappa & 0,73 & & & & & & \\
\hline
\end{tabular}

Sumber : Pengolahan Data, 2016; Data Lapangan, Oktober 2016

Berdasarkan Tabel 3 prediksi lebih mudah dilakukan pada kelas erosi sangat berat, sangat ringan dan ringan. Karena batasan antara kelas erosi sangat tegas perbedaan kenampakan indikator erosinya di lapangan dengan lereng landai sampai sangat curam sedangkan kelas erosi berat lebih sulit dibedakan dengan erosi sangat berat karena memiliki kenampakan indikator erosi yang sama.

\section{Kesimpulan}

Hasil model prediksi menunjukan distribusi tingkat erosi yang dominan di daerah kajian yaitu erosi sangat berat $(35,44 \%)$ tersebar di sebagian besar kecamatan Kokap, Girimulyo dan sebagian Pengasih. Hasil pengamatan indikator di lapangan menunjukan DAS Serang termasuk area yang rentan terhadap erosi. Model kualitatif yang dihasilkan dapat digunakan sebagai metode alternatif yang lebih efektif dan efisien untuk prediksi erosi.

\section{Saran}

Penelitian ini dilakukan sebagai bagian dari upaya membangun logika model erosi secara kualitatif yang sesuai dengan kondisi di Indonesia sehingga menjadi solusi cepat prediksi erosi tanpa mengandalkan logika model yang selama ini banyak digunakan seperti USLE dan turunannya. Oleh karena itu, metode yang dilakukan dalam penelitian ini perlu diuji di lokasi penelitian yang berbeda.

\section{Ucapan Terimakasih}

Ucapan terimakasih disampaikan kepada Kementrian Pendidikan Tinggi yang telah membiayai penelitian ini dan Lembaga Penerbangan dan Antariksa yang telah menyediakan data

\section{DAFTAR PUSTAKA}

Alexakis, D.D., Hadjimitsis,D.G., Agapiou. 2013. Integrated Use of Remote Sensing,GIS and Precipitation Data for The Assesment of Soil Erosion Rate In the Catchment Area of "Yialias" in Cyprus. Atmospheric Research (131): 108-124. 
Arif, N., Danoedoro, P. 2013. An Analyze of A Backpropagation Neural Network in The Identification of Critical Land Based on ALOS Imagery. 34th Asian Conference on Remote Sensing 2013, Volume 1, pp 589 - 593.

Arsyad, S. 2010. Konservasi Tanah dan Air, Edisi Kedua, IPB Press

Asis, A., Omasa, K. 2007. Estimation of Vegetation Parameter for Modeling Soil Erosion Using Linear Spectral Mixture Analysis of Landsat ETM Data. ISPRS Journal of Photogrametry \& Remote Sensing 62, pp.309-324

Assouline, S., Ben-Hur, M. 2006. Effect of Rainfall Intensity and Slope Gradient on The Dynamics of Interill Erosion During Soil Surface Sealing". Catena 66 : 211 $-220$

Bredeweg, B., Linnebank, F., Bouwer, A., Liem, J. 2009.Garph3-Workbench for Qualitative Modelling and Simulation. Ecological Informatics (4): 263-281

Chen, Y.R., Chen, J.W, Hsieh, S.C., Ni, P.N. 2013. The Application of Remote Sensing Technology to The Interpretation of LU for Rainfall - Induced Landslide Based on Genetic Algorithm and Artificial Neural Network, IEEE Earth Observations and remote Sensing, Vol.2 (2): 87 - 95

Farhan, Y.,Zregat, D., Farhan, I. 2013. Spatial Estimation of Soil Erosion Risk using RUSLE Approach, RS, and GIS Techniques: A Case Study of Kufranja Watershed, Northern Jordan, Journal of Water Resource and Protection (5): $1247-1261$

Gutman, G., Ignatov, A. 1998. The Derivation of The Green Vegetation Fraction from NOAA/AVHRR Data for Use in Numerical Weather Prediction Models. International Journal of Remote Sensing 19 (8),1533-1543

Horton, R.E. 1945. Erosional Development of Streams and Their Drainage Basins: Hydrological Approach to Quantitative Morphology. Geol.Soc.Bull. 56:275- 243

Kamaludin, H., Lihan, T., Rahman, Z.A., Mustapha, M.A., Idris, W.M.R and Rahim, S.A. 2013. Intergration of Remote Sensing, RUSLE and GIS to Model Potential Soil Loss and Sediment Yield (SY). Hydrol. Earth Syst. Sci. Discuss, 10, 4567 - 4569

Liao, Z., Wang, B., Xia, X., Hannam, P.M. 2012. Enviromental Emergency Decission Support System Based on Artificial Neural Network. Safety Science 50, pp. 150163

McCool, D.K., Brown, L.C., Foster, G.R. 1989. Revised Slope Length Factor for The Universal Soil Loss Equation. Transaction of ASAE 32 (5), 1571 - 1576

Melchiorre, C., Matteuci, M., Azzoni, A. ,Zanchi, A. 2008. Artificial Neural Networks and Cluster Analysis in Landslide Susceptibility Zonation. Geomorphology 94, pp. 379-400.

Pradhan, B., Lee, S. 2007. Utilization of Optical Remote Sensing Data and GIS Tools for Regional Landslide Hazard Analysis Using an Artificial Neural Network Model. Earth Science Frontiers, 14 (6):143 - 152.

Pradhan, B., Lee, S., Buchroitner, M.F. 2010. A GIS-Based Backpropagation Neural Network Model And Its CrossApplication and Validation for Landslide for Susceptibility Analyses. Computers, Environment and Urban Systems 34:216-235.

Purnomojati, L., 2016. Evaluasi Water Yield (Hasil Air) Melalui Pemodelan Hidrologi dan Skenario PL (Kasus Di DAS Serang, Kulonprogo). Tesis Fakultas Geografi UGM. Yogyakarta
Renard, K.G., G.R. Foster, G.A. Weesies, D.K. McCool, and D.C. Yoder, coordinators. 1997. Predicting Soil Erosion by Water: A Guide to Conservation Planning With The Revised Universal Soil Loss Equation (RUSLE). U.S. Department of Agriculture, Agriculture Handbook No. 703, 404 pp.

Santoso, H.B. 2012. Arahan Penggunaan Lahan Optimal Berdasarkan Aspek Biofisik dan Kebutuhan Minimal Lahan Pertanian untuk Pengendalian Erosi di Das Serang. Tesis, Fakultas Kehutanan UGM. Yogyakarta

Song, H., Xu, R., Ma, Y., Li, G. 2013. Classification of ETM+ Remote Sensing Image Based on Hybrid Algorithm of Genetic Algorithm and Backpropagation Neural Network, Hindawi Publishing Corporation, Mathematical Problems Engineering Vol. 2013. http://dx.doi.org/10.1155/2013/719756

Sonneveld, B.G.J.S., Keyzar, M.A., Stroosnijder, L. 2011. Evaluating Quantitative and Qualitative: An Application for Nationwide Water Erosion Assesment in Ethiopia. Enviromental Modelling \&Software (26):1161-1170.

Stocking, M., Murnaghan, N. 2000. Land DegradationGuidelines For Field Assessment. Overseas Development Group, University of East Anglia, Norwich UK

Vrieling, A., Sterk G., Vigiak O. 2006. Spatial Evaluation of Soil Erosion Risk In The West Usambara Muntains, Tanzania. Land Degradation 17: 301 - 319

Ypsilantis, W.G. 2011. Upland soil erosion monitoring and assessment: An overview. Tech Note 438. Bureau of Land 